\title{
Peluang Usaha Budidaya Ikan Lele Sistem Akuaponik Berteknologi Bioflok di Desa Purwoasri, Tegaldlimo, Banyuwangi
}

\author{
Business Opportunities for Catfish Aquaculture with Biofloc Technology in Purwoasri \\ Village, Tegaldlimo, Banyuwangi
}

\author{
Suciyono $^{1 *}$, Muhammad Faizal Ulkhaq ${ }^{1}$, Prayogo', Rakian Rizki Dermawan ${ }^{2}$, Dian \\ Putri Apriliani², Novia Salmatin ${ }^{2}$, Muhammad Hilmy Maulana², Dinda Yuni Istanti ${ }^{2}$ \\ ${ }^{1}$ Program Studi Akuakultur, Fakultas Perikanan dan Kelautan, \\ Universitas Airlangga, Kampus C Mulyorejo, Surabaya 60115, Indonesia, \\ ${ }^{2}$ Mahasis wa Program Studi Akuakultur, Fakultas Perikanan dan Kelautan, \\ PSDKU Universitas Airlangga, J1. Wijaya Kusuma No.113, Banyuwangi 68425, Indonesia \\ *Corresponding author: $\underline{\text { suciyono@gmail.com }}$
}

\begin{abstract}
Abstrak
Budidaya ikan lele dengan sistem kombinasi akuaponik dan bioflok merupakan sistem terpadu yang dinilai efektif dan efisien. Sistem akuaponik mereduksi amonia dengan menyerap air buangan budidaya atau air limbah dengan menggunakan akar tanaman. Bioflok merupakan sistem budidaya ikan intensif yang memanfaatkan prinsip daur ulang nutrien pakan yang terbuang melalui bakterial. Tujuan dilaksanakannnya pengabdian masyarakat sebagai upaya pengenalan budidaya ikan lele dengan sistem kombinasi akuaponik dan bioflok kepada masyarakat di Desa Purwoasri, Tegaldlimo, Banyuwangi. Kegiatan dilaksanakan pada bulan Juni-Oktober 2019, terdiri dari pengenalan sistem budidaya pada masyarakat melalui sosialisasi dan pelatihan serta pendampingan pelaksanaan budidaya ikan lele dengan sistem kombinasi akuaponik dan bioflok dalam bentuk bangunan/demplot. Selanjutnya dilakukan evaluasi kepada mitra melalui pre-tes dan post-tes dan diakhiri dengan pembentukan kader. Kegiatan pengenalan sistem budidaya dilakukan kepada mitra yang terdiri dari PKK dan anggota karang taruna di desa Purwoasri sebanyak 20 orang. Berdasarkan evaluasi selama kegiatan ini berlangsung diketahui bahwa pengetahuan mitra tentang sistem budidaya meningkat hingga $75 \%$ dari evaluasi awal sebesar $40 \%$. Selain itu, ketertarikan mitra terhadap sistem ini juga mengalami peningkatan dari $65 \%$ menjadi $89 \%$. Hal ini menunjukkan bahwa kegiatan pengabdian masyarakat memberikan dampak positif bagi mitra.
\end{abstract}

Kata kunci: pengabdian masyarakat, akuaponik, bioflok, Banyuwangi

\begin{abstract}
Catfish aquaculture with a combination of aquaponics and biofloc is an integrated system that is effective and efficient. In the aquaponic system aquaculture wastewater such as ammonia has been reduced by plant roots. Biofloc is an intensive fish culture system that utilizes the principle of recycling feed nutrients that are wasted through bacteria. The aim of community empowerment was to introduce of catfish aquaculture with a combination of aquaponic and bioflock systems to the community in Purwoasri Village, Tegaldlimo, Banyuwangi. This activity was carried out in June-October 2019, which consisted of introducing the cultivation system to the community through socialization and training, as well as mentoring the implementation of cultivation in the form of buildings/demonstration plots. Furthermore, evaluations are carried out to partners through pre-test and post-test and end with the formation of cadres. The introduction of the cultivation system was carried out to partners consisting of PKK and members of the Purwoasri Village Youth Organization as many as 20 people. Based on the evaluation during this activity, it was found that the partner's knowledge about the cultivation system increased to $75 \%$ from the initial evaluation of $40 \%$. In addition, an az partner interest in the system also increased from $65 \%$ to $89 \%$. It showed that community empowerment activities had a positive impact on partners.
\end{abstract}

Key words: community empowerment, aquaponics, biofloc, Banyuwangi

Received: 1 Oktober 2019

Revised: 31 Oktober 2019

Accepted: 21 November 2019 


\section{PENDAHULUAN}

Kabupaten Banyuwangi mempunyai luas wilayah lebih dari 5.7 juta $\mathrm{km}$, dengan garis pantai sekitar $175.8 \mathrm{~km}$ dengan jumlah penduduk lebih dari 1.9 juta jiwa (Banyuwangikab.go.id, 2019). Potensi tersebut terdiri dari pertanian, perkebunan, perikanan, serta pariwisata yang terbentang dari Kecamatan Wongsorejo dibagian utara sampai dengan Kecamatan Tegaldlimo dibagian selatan (Bapeda Banyuwangi, 2017). Kecamatan Tegaldlimo memiliki sembilan desa/kelurahan yang memiliki banyak sekali potensi seperti pada Desa Purwoasri dan Purwoagung. Desa Purwoasri dan Purwoagung merupakan desa dengan jumlah penduduk masing masing sebesar 4.603 dan 4.037 jiwa, dengan sebaran pekerjaan masyarakat seperti tersaji pada (Gambar 1). Dominasi aktifitas masyarakat berprofesi sebagai petani, peternak, berkebun dan kegiatan perikanan, serta sebagian kecil bergerak pada sektor wiraswasta dan jasa (BPS Banyuwangi, 2017).

Tingginya masyarakat yang berprofesi sebagai petani perikanan merupakan potensi yang besar mengingat banyak program-program pemerintah Kabupaten Banyuwangi yang berorientasi pada sektor tersebut. Berbagai event pada sektor perikanan membuat peluang usaha semakin besar. Namun, hal tersebut dapat tercapai apabila pembudidaya ikan yang ada di wilayah tersebut mampu bersaing dengan pembudidaya lokal maupun luar baik kualitas maupun kuantitas.

Kualitas dan kuantitas produksi budidaya memberikan dampak positif bagi pelaku usaha perikanan jika mampu berproduksi secara berkelanjutan. Permasalahan yang ada sampai saat ini diantaranya para pembudidaya masih melakukan kegiatan budidaya secara ektensif. Sehingga perlu dilakukan optimalisasi budidaya yang mengarah pada diversifikasi usaha yang difokuskan pada peningkatan pendapatan pembudidaya. Berdasarkan hal tersebut, perlunya dilakukan berbagai perbaikan diantaranya sumber daya manusia (SDM), sarana dan prasarana serta distribusi hasil produksi. Selama ini yang menjadi permasalahan pada para pembudidaya yakni nilai jual yang rendah serta cost produksi yang terlalu tinggi sehingga keuntungan yang didapatakan sangat minimalis. Salah satu system budidaya yang sangat mungkin menjadi solusi bagi pembudidaya yakni budidaya ikan lele dengan system akuaponik berteknologi bioflok.

Akuaponik merupakan biointegrasi yang menghubungkan akuakultur berprinsip resirkulasi dengan produksi tanaman atau sayuran (Driver, 2006). Sedangkan teknologi bioflok merupakan salah satu alternatif dalam mengatasi masalah kualitas air dalam akuakultur yang diadaptasi dari teknik pengolahan limbah domestik secara konvesional dengan bantuan mikroorganisme (Avnimelech, 2006). Penggabungan budidaya ikan dengan sistem akuaponik berteknologi bioflok akan memaksimalkan produksi ikan dan sayuran pada lahan yang sempit sehingga bersifat efisien.

\section{METODE PENELITIAN}

Program pengabdian masyarakat ini dilaksanakan pada Bulan Juni sampai Oktober 2019 yang terdiri dari 20 orang peserta dari dua kelompok pembudidaya ikan. Peserta berasal dari kelompok pembudidaya ikan yang digerakkan oleh kepala Desa Purwoasri. Sosialisasi program dilaksanakan pada kelompok pembudidaya balai Desa Purwoasri. Selanjutnya, dilakukan evaluasi melalui pre-tes dan post-tes sebagai evaluasi pengetahuan mitra. Metode yang digunakan dalam pelaksanaan kegiatan pengabdian kepada masyarakat ini dilakukan dalam lima tahap kegiatan meliputi:

\section{Pre-Tes dan Pengenalan Metode Budidaya}

Peserta dibagikan lembar pre-tes yang bertujuan untuk mengetahui tingkat pemahaman awal terhadap metode budidaya ikan dengan sistem akuaponik dan bioflok. Selanjutnya, setelah dilakukan pre-tes dilakukan pengenalan metode budidaya sistem akuaponik dan biflok yang terdiri dari definisi sistem, sarana yang dibutuhkan, aplikasi penggunaan, keuntungan dari sistem, kendala sistem serta peluang penggunaan sitem. 


\section{Praktik Penyiapan Budidaya Ikan Lele}

Pembuatan demplot atau sarana budidaya sistem akuaponik dan bioflok. Peserta melakukan pembuatan demplot budidaya ikan secara langsung dengan beberapa metode dan bahan yang telah disiapkan, sedangkan mitra menyediakan lahan dan sumber listrik dan air sebagai sarana kegiatan budidaya.

\section{Praktik Budidaya Sistem Akuaponik Bioflok}

Praktik budidaya ikan dilakukan setelah pengenalan program dan pembuatan demplot selesai dilakukan. Praktik budidaya diawali dengan manajemen kualitas air dan pembuatan bioflok selama 7 hari. Setelah itu dilakukan penebaran benih, manajemen pakan, manajemen kesehatan ikan dan panen. Rangkaian kegiatan ini membutuhkan waktu \pm 3 bulan.

Tahap selanjutnya yakni evaluasi hasil kegiatan budidaya, analisa usaha dan analisis kualitas air, sehingga output dari tahap evaluasi yakni informasi tentang kelayakan program berdasarkan aspek ekonomi dan ekologi dapat diketahui.

\section{Pembentukan Kader}

Program pembentukan kader dilakukan untuk menjaga keberlanjutan (sustainability) program pengabdian masyarakat. Kader yang dipilih dibekali seperangkat instrument pengaplikasian kegiatan budidaya ikan.

\section{Evaluasi Kegiatan}

Tahap akhir dari program pengabdian masyarakat dilakukan post-tes dengan form yang telah dipersiapkan. Tujuan dilaksanakan post-tes untuk mengetahui perbedaan pengetahuan mitra sebelum dan sesudah kegiatan ini berlangsung. Data yang diperoleh dari penelitian ini ditampilkan dalam bentuk grafik dan dilakukan analisa secara deskriptif.

\section{HASIL DAN PEMBAHASAN}

\section{Demplot Budidaya Sistem Akuaponik Teknologi Bioflok}

Pembuatan demplot budidaya terdiri dari pembuatan kolam dan kerangka untuk kegiatan budidaya dan penyiapan sarana atau media hidroponik. Pemasangan kerangka dan kolam dengan meluruskan gulungan rangka besi dan dibentuk menjadi bulat dengan diameter $2 \mathrm{~m}$. Setelah itu pemasangan pelindung karet didalam kerangka yang berfungsi sebagai pelindung terpal kolam sehingga tidak langsug bersentuhan dengan rangka besi. Setelah itu dilanjutkan dengan pemasangan terpal dan pemasangan outlet pada kolam terpal. Akuaponik dipasangan dengan susunan bertingkat sebanyak 4 tingkat. Akuaponik diletakkan pada dinding tepat diatas kolam terpal. Akuaponik dibuat dari pipa dengan diameter untuk pot yaitu $4 \mathrm{~cm}$ dan jaraknya 10 $\mathrm{cm}$ antar lubang, dan ditumpu pada kayu dan besi yang diletakkan di atas kolam (Gambar 2). Pemasangan pompa berfungsi sebagai sirkulasi dan pengisian air sebagai media budidaya ikan.

Proses penyemaian dilakukan dengan menyiapkan rockwoll berdiameter $4 \times 4 \mathrm{~cm}$ dan dilubangi bagian tengahnya. Biji putsoi ditanam pada media rockwoll yang telah dibasahi. Masing - masing Rockwoll mampu ditanami 2-3 biji putsoi. Putsoi dibiarkan terkena sinar matahari setelah sehari sebelumnya disimpan di tempat tertutup (Driver, 2006).

\section{Pengenalan dan Pendampingan Kegiatan Budidaya kepada Mitra}

Pengenalan sistem budidaya dilakukan kepada mitra yang terdiri dari anggota kelompok Pemberdayaan Kesejahteraan Keluarga (PKK) dan anggota karang taruna di Desa Purwoasri sebanyak 20 orang. Selain mitra, kegiatan ini juga diikuti oleh aparatur desa Purwoasri. Kegiatan pengenalan sistem budidaya terdiri dari: cara pembuatan akuaponik, komoditas yang dibudidayakan, sistem budidaya dan manajemen budidaya serta monitoring kegiatan budidayan (Gambar 3).

Materi sosialisasi disampaikan oleh tim pengabdian masyarakat Fakultas Perikanan dan Kelautan Universitas Airlangga. Pelaksanaan kegiatan ini melibatkan pre-tes dan diskusi untuk menggali pengetahuan kelompok terkait dengan kegiatan budidaya dan aplikasi sistem (Gambar $3)$. 


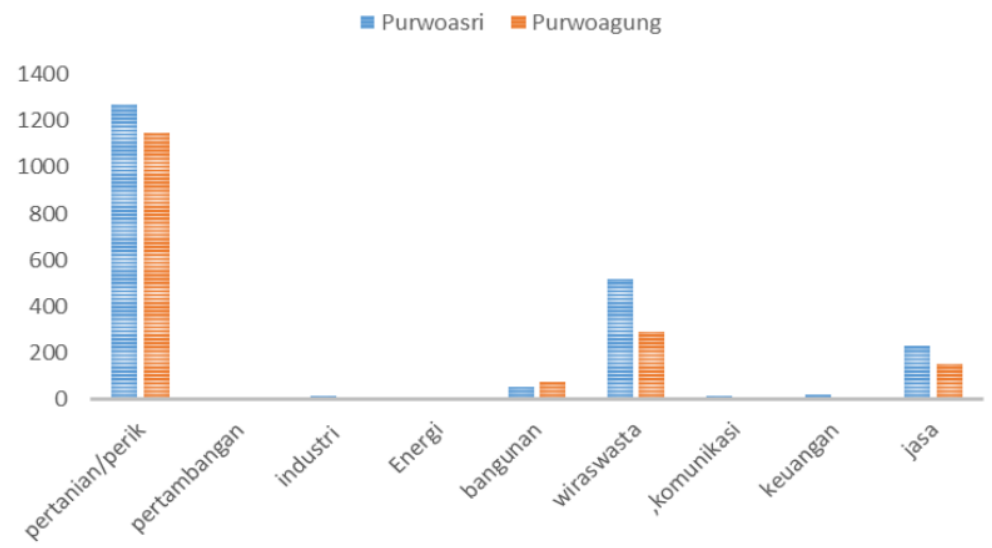

Gambar 1. Sebaran pekerjaan masyarakat berdasarkan sektor
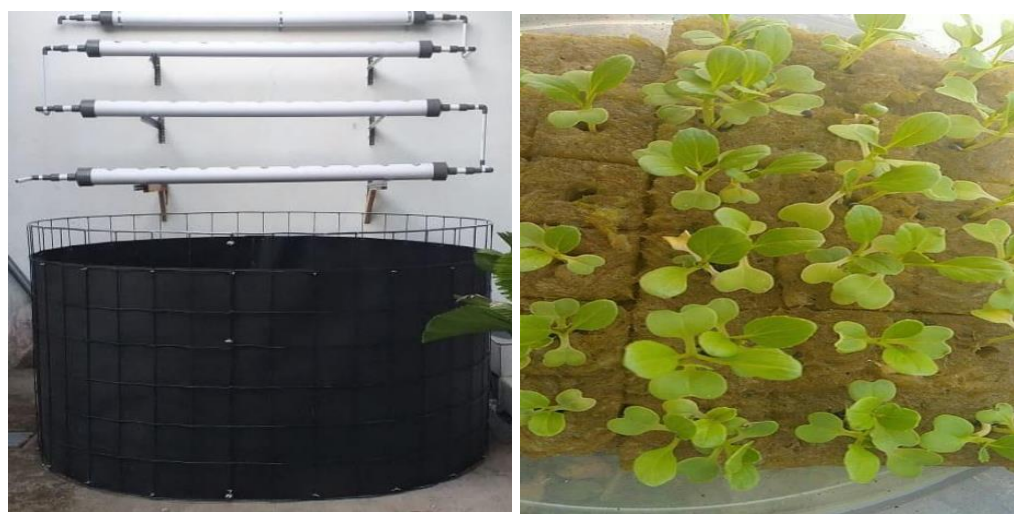

Gambar 2. Demplot budidaya akuaponik, media budidaya, media tanam dan jenis tanaman

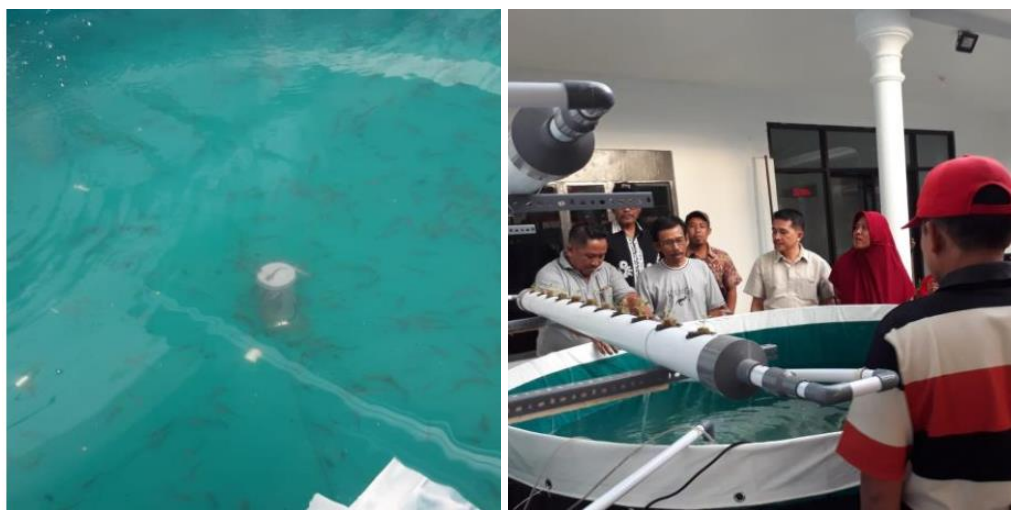

Gambar 3. Pendampingan lapang praktik budidaya lele sistem akuaponik berteknologi bioflok

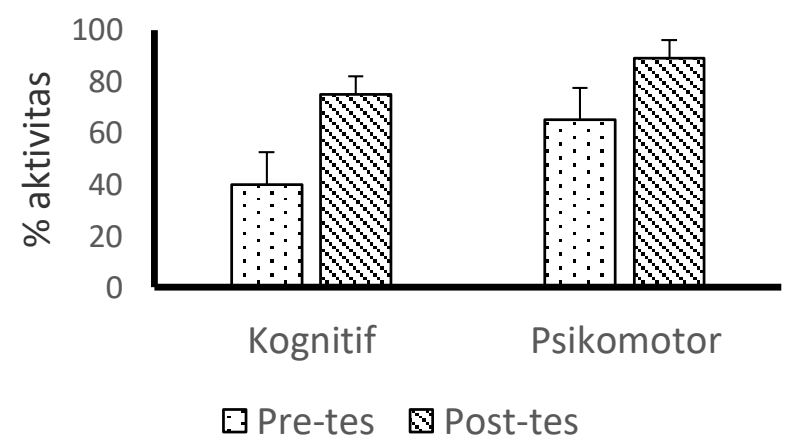

Gambar 4. Grafik perubahan prilaku dari hasil evaluasi pre dan post-tes 


\section{Aplikasi Budidaya Ikan dan Monitoring}

Kegiatan budidaya dilakukan selama satu siklus dan dilakukan monitoring secara rutin bersama mitra sampai panen. Kegiatan ini dimaksudkan untuk meningkatkan keterampilan mitra dalam pemeliharaan ikan lele yang dibudidayakan dengan sistem akuaponik. Selain itu, dilakukan pemeriksaan terhadap kualitas air, untuk mengetahui kualitas air selama kegiatan budidaya. Parameter produksi budidaya seperti; SR (Survival Rate) atau tingkat kelangsungan hidup ikan lele, pertumbuhan harian dan spesifik (SGR dan GR), manajemen pakan, manajemen kesehatan ikan serta pemanenan. Pencatatan SR dari ikan lele yang dibudidayakan sangat penting untuk menentukan persentase kelangsungan hidupnya. Penentuan SR dilakukan pada akhir budidaya sebagai evaluasi kegiatan budaya tearsebut.

Adapun aplikasi kegiatan budidaya yang dilakukan adalah:

\section{Penebaran benih dan penye maian tanaman air}

Benih ikan lele yang ditebar sebanyak 3.000 ekor dengan ukuran 10-12 cm. Penebaran benih dilakukan pada sore hari yang telah diaklimatisasi. Monitoring dilapangan menunjukan kondisi benih dalam keadaan sehat, selanjutnya, pemeriksaan terhadap tumbuhan yang ditanam dengan menyiangi daun yang menguning dan yang mati harus dibuang. Selain itu, permasalahan lain juga dicatat sebagai bahan evaluasi.

\section{Monitoring rutin kualitas air}

Kualitas air seperti: warna, bau, selama pemeliharaan menunjukan kondisi yang normal, dimana warna air budidaya berwarna hijau kebiruan. Hal ini menunjukan bahwa kualitas air mengandung nutrient bagi pertumbuhan plankton. Sedangkan, bau air kolam budidaya secara fisik masih dalam kondisi ideal, hal ini dibuktikan dengan hasil pengukuran kadar amoniak masih dibawah $1 \mathrm{ppm}$. Amoniak dalam perairan mampu menghasilkan bau yang tidak nyaman (Gumelar, 2017). Kondisi tersebut menunjukan bahwa tanaman air dalam sistem ini mampu mereduksi limbah budidaya. Sistem akuaponik mampu mereduksi limbah budidaya ikan seperti amoniak (Nugroho dkk, 2012; Dauhan, 2014).

\section{Manajemen pemberian pakan}

Pemberian pakan diberikan dua kali sehari (pagi dan sore), hal ini dilakukan untuk meminimalisir stress serta mengoptimalkan pemanfaatan pakan. Dosis pakan yang digunakan pada sistem budidaya ini sebesar 4$5 \%$ dari total biomass dengan kandungan protein 28-30\%, hal ini dimaksudkan untuk mengoptimalkan penggunaan pakan. Primashita dkk (2017), melaporkan optimalisasi pakan pada sistem budidaya akuaponik dapat meminimalisir limbah budidaya yang berdampak terhadap daya tahan komoditas budidaya.

\section{Output terhadap mitra}

Berdasarkan evaluasi selama kegiatan berlangsung diketahui bahwa pengetahuan mitra tentang sistem budidaya meningkat hingga $75 \%$ dari evaluasi awal sebesar 40\%. Ketertarikan mitra terhadap sistem ini juga mengalami peningkatan dari 65\% menjadi 89\% (Gambar 4). Hal ini menunjukkan bahwa kegiatan pengabdian masyarakat memberikan dampak positif bagi mitra.

\section{KESIMPULAN}

Budidaya ikan lele sistem akuaponik berteknologi bioflok dapat diaplikasikan di lokasi mitra. Peningkatan pengetahuan mitra tentang budidaya sistem akuaponik berteknologi bioflok meningkat secara signifikan sebesar $75 \%$ serta ketertarikan mitra mencapai $89 \%$.

\section{UCAPAN TERIMA KASIH}

Penulis mengucapkan terima kasih kepada Lembaga Pengabdian dan Pengembangan Masyarakat (LPPM) Universitas Airlangga sebagai founder kegiatan ini.

Fakultas Perikanan dan Kelautan Universitas Airlangga yang telah mensukseskan pelaksanaan kegiatan ini, serta pihak-pihak yang terlibat selama kegiatan ini berlangsung. 


\section{DAFTAR PUSTAKA}

Avnimelech, Y. 2006. Bio-filter: The Need for An New Comprehensive Approach. Aquac. Eng., 34, 172-178.

Primashita, A.H., Rahardja, B.S., Prayogo. 2017. Pengaruh Pemberian Probiotik Berbeda dalam Sistem Akuaponik terhadapLaju Pertumbuhan dan Survival Rate Ikan Lele (Clarias sp.). J. Aquaculture Sci., 1: 1 -9.

Badan Perencanaan dan Pembangunan Daerah (BAPEDA). 2017. Profil Badan Perencanaan dan Pembangunan Daerah (BAPEDA) Kabupaten Banyuwangi 2017. BAPEDA. Banyuwangi.

Badan Pusat Statistik Kabupaten Banyuwangi. 2017. Kecamatan Tegaldlimo dalam Angka. Badan Pusat Statistik. Banyuwangi.

Banyuwangikab.go.id. 2019. Gambaran Umum Kabupaten Banyuwangi. https://www. banyuwangikab.go.id.
Driver, S. 2006. Aquaponics - Integration of Hidroponics with Aquaculture. ATTRANational Sustainable Agriculture Information Service (National Center for Appropriate Technology).

Dauhan, R.E.S., Efendi. E., Suparmono. 2014. Efektifitas Sistem Akuaponik Dalam Mereduksi Konsentrasi Amonia Pada Sistem Budidaya Ikan. J. Rekayasa Teknol. Budidaya Perairan, 3, 297-302.

Nugroho, R.A., Pambudi, L.T., Chilmawati, D., Haditomo, A.H.C. 2012. Aplikasi Teknologi Aquaponic Pada Budidaya Ikan Air Tawar Untuk Optimalisasi Kapasitas Produksi. J. Saintek Perikanan, 8, 46-51.

Gumelar, W.R., Nurruhwati, I., Sunarto, Zahidah. 2017. Pengaruh Penggunaan Tiga Varietas Tanaman Pada Sistem Akuaponik Terhadap Konsentrasi Total Amonia Nitrogen Media Pemeliharaan Ikan Koi. J. Perikanan Kelautan, 8, 36-42 